\title{
A POESIA DE INVENÇÃO NA VOZ DO ESTRANHAMENTO
}

\author{
Beatriz H. Ramos Amaral'
}

"C'est la poésie qui nous protege

contre l'automatisation"

(Roman Jakobson, "Quest-ce la poésie?",

Huit Questions de Poétique)

Abrir a luz-poesia. Nos caminhos da hibridização de linguagens e de expressões estéticas e de comunicação, persiste lúcida-lúdica e vibrante a poesia de invenção, que abre frestas sígnicas, semânticas, sinestésicas, formais, conceituais, filosóficas para o leitor e o convida e convoca para uma ação, dele pedindo uma resposta cri/ativa. E desautomática. É a poesia que se erige pela visualidade/sonoridafe, a poesia que circula nos rumos da verbivocovisualidade preconizada desde os primórdios do movimento da poesia concreta no Brasil. É a poesia que recebe fragmentos de ideais das cartas programáticas dos movimentos de vanguarda do início do século $X X$, a poesia que se desenha e se faz caligrafia, e se manuscreve e se conecta, nas intersecções entre épocas e âncoras, com a força viva do ostrânienie (o estranhamento). Esta constelação de grafemas a trafegar sincronicamente pelo universo aberto da holografia, da música nova, eletrônica, serial ou acústica, eletro-acústica, que recebe constantes sugestões de renovação também alimentada pelo desenvolvimento dos meios tecnológicos, é parte significativa da poesia de invenção.

O polifônico conjunto de poemas e poetas convidados para esta edição de EUTOMIA constitui um universo gerado pela música de câmara, pelo som pop das ruas, pelo inconformismo diante das adversidades do cotidiano, pelo rigor estético, pelas perplexidades que se multiplicam no indescritível dos ânimos, na vocação 
crítica, transgressora e sensível da própria essência da poesia. E de sua concisão. A face desta poética, ora refinadamente zen, como em Élson Fróes ou de impactante e elétrica vibração, como em Tadeu Jungle, ora galáctica, como em Walt B. Blackberry, ora digital de plena expressão, como em André Vallias, ora metassilábica e oceânica, como em Julio Mendonça, ora poesi'arte, como em Edgard Braga, Lenora de Barros, Arnaldo Antunes e Omar Khouri, ora verbovisual e metassilábica, como em Carlos Ávila e Beatriz H. R. Amaral, é sempre construída pelo olhar crítico.

Como afirma Carlos Ávila, "pelas frestas o poeta inocula seu concentrado pensamento crítico" (Poesia Pensada, 7 Letras, 2004). A poesia segue na contramão de um discurso lógico convencional. O poeta incendeia de desafios os instrumentos de sua própria vertigem individual, da vertigem coletiva de seu tempo, e da insanidade e do caos que a realidade lhe impõe. Mas recria com singularidades construtivas o desconcerto do insólito na confluência de oceanos. O poeta rega com invenção a vitalidade da poesia. Adestra seus instrumentos. Amanhece como noite, desanoitece aurora. Pros/segue.

Segue pelas noites semifusas de grafemas despertos, acesos e plenamente abertos, por uma mescla de cores em que algo se desprende do tempo e se expande na dança de fractais. O poeta colhe elementos sensórios na ultrapágina, na tela, no objeto escrito, nas faces de fugidias sílabas semínimas para encontrar o movimento, as órbitas, o corpo, a coreografia. A tactilidade e o engenho. A luz caligráfica na hipótese grávida de sentidos. Caminha assim pelo plâncton de signos. Plantando sementes numa instigante cartografia. Peixes que se procuram, alinhando afinidades e ressaltando o instante luminoso da leitura da obra aberta. Para inventar e reinventar as labaredas da palavra acesa.

Nesta edição, homenageamos Augusto de Campos, a poesia e o pensamento do extraordinário poeta brasileiro que cria e constrói, magistralmente, há mais de seis décadas, o universo em expansäo da vibração poética. E nos conduz a todos a desafiar as fronteiras da arte-luz-poesia. Para ele os nossos maiores agradecimentos.

\footnotetext{
' Poeta, contista, musicista, Mestre em Literatura em Crítica Literária pela PUC-SP, também formada em Direito pela USP. Autora de 15 livros, entre os quais A Transmutação Metalinguística na Poética de Edgard Braga (Ateliê Editorial, coleção estudos literários, crítica, 2013), Peixe Papiro (Scortecci, São Paulo, 2018), Os Fios do Anagrama (contos, RG Editores, SP) e “O Avesso do Arquipélago" (2019, Lisboa, poesia). Coordenou ciclos literários na Secretaria Municipal de Cultura entre 1994 e 1997 e na Casa das
} 
Rosas (2013 e 2014). Foi membro do MPSP de 1986 a 2016. Secretária-geral e Diretora da UBE-SP de 1996 a 2004. É Diretora de Publicações do MPD. Endereço eletrônico: beatrizhramaral@uol.com.br. 